\title{
The EU childcare strategy in times of austerity
}

\author{
Annick Masselot
}

\begin{abstract}
The importance of accessible, affordable, flexible and high quality childcare facilities is acknowledged by the European Union (EU) as an essential element to achieving gender equality and full employment for parents. However, legal and policy development in this area has been slow and without coherence. Following the 2008 financial crisis, EU intervention on childcare issues appears to have been dictated by economic priorities and by the rights of the child. The early underpinning of childcare policy with the principle of gender equality is fading fast. This article argues that to date childcare remains dominated by rhetoric: the targets set are far from being achieved, disparities between Member States continue to occur, and women in Europe continue to disproportionately bear the cost of reproduction. In this context, childcare remains gendered, unvalued, unaccounted for and often unpaid.
\end{abstract}

Keywords: Austerity, childcare, EU, gender-equality, reconciliation, work-family

\section{Introduction}

This article focuses on the engagement of European Union (EU) law with childcare, an area that has only recently started being discussed as a political issue significant to European integration. Childcare is a component of work-family reconciliation law and policy, which is itself an integral part of the EU employment-led social policy (European Commission 2010a). EU work-family reconciliation law and policy is traditionally articulated around three types of legal provisions: leave and time measures as well as a childcare strategy. The first two types of measures grants parents time off in connection with the birth of the child (the

\footnotetext{
* Associate Professor in Law, University of Canterbury, New Zealand.
} 
Final draft (20/06/2015) of an article submitted and accepted for a special issue of the Journal of Social Welfare \& Family Law on 40 Years of Work/Life Balance in the EU: Achievements and Limitations

Pregnant Workers Directive 92/85/EEC O.J. [1992] L348/1; the Parental Leave Directive 2010/18/EU O.J. [2010] L68/13, and the possibility of re-arranging working hours to fulfil their family responsibilities (the Part-Time Directive 97/81/EC O.J. [1998] L14/9, the FixedTerm Directive1999/70/EC O.J. [1999] L175/43 and the Working-Time Directive 2003/88/EC O.J. [2003] L299/9). These provisions are legally binding and are part of employment law. By contrast, the childcare strategy, despite being essential to ensure that individuals (mostly women) with unpaid care responsibilities can participate and remain in the employment market (Lewis 2008), is neither employment law based nor is it legally binding. Rather it is located in the realm of social welfare and includes a number of soft measures which aim to encourage Member States to develop accessible, affordable and quality childcare facilities as well as other forms of financial assistance towards childcare.

This article argues that the EU has an obligation to lead policy and legislation aimed at developing a coherent and effective childcare strategy for the Union. This is mainly for two interconnected reasons. First, the establishment of childcare measures will help to realign the uneven distribution of domestic work between men and women in order to limit the "double shift" (Hochschild and Machung 1989) worked by many women and thus achieve gender equality. Secondly, there is a clear link between childcare and the realisation of the objectives of the internal market. Structured childcare will give women more time to participate in the employment market. Indeed the 1997 European Employment Strategy (EES) established that employment rates needed to increase to fit in with the EU's growth strategy. Under this policy, women have been targeted as the largest group to be "activated" into the labour market, thus providing the EU with legitimate, albeit indirect competence in the area of childcare.

This article considers the EU's childcare strategy direction before and after the financial crisis. For this purpose, it is divided into three sections. The first section explores the difficulties in developing a childcare strategy at the EU level. The following section considers the principles which underpinned EU childcare policy development prior to the 2008 global financial and economic crisis. The third section examines how the 2008 crisis has impacted on the development of the EU childcare strategy in its aftermath. The conclusion offers thoughts regarding the future shape of EU childcare strategy. 
Final draft (20/06/2015) of an article submitted and accepted for a special issue of the Journal of Social Welfare \& Family Law on 40 Years of Work/Life Balance in the EU: Achievements and Limitations

\section{The difficulties in building a EU childcare strategy}

Although childcare has been defined as a strategic avenue for addressing fundamental economic and social problems (Council Recommendation 92/241/EEC O.J. [1992] L123/16 (European Commission 1992); Presidency Conclusions SN 100/1/02 REV 1; European Commission Recommendation 2013/112/EU O.J. [2013] L59 (European Commission 2013a), little has been done in terms of policy development at EU level. This article identifies three main reasons that might explain this lack of intervention. First, as the rationale of childcare is based on the twin objectives of achieving gender equality on the one hand, and economic competitiveness, increasing employment rates and addressing the demographic challenges of an ageing society on the other (Lewis 2006, Radulova 2009), it embodies the traditional tension between the EU's economic imperative and its fundamental rights aspiration (Garcia and Masselot 2015b).

Gender equality is "one of the central missions and activities of the Union" (Bell 2011, p. 629). Indeed, Article 2 of the Treaty on European Union (TEU) proclaims that equality is one of the values on which the Union is founded and has been confirmed as a constitutional fundamental right legally guaranteed by Article 23 of the EU Charter of Fundamental Rights (see also Koukoulis-Spiliotopoulos 2008). As the EU work-family reconciliation law and policies are strongly underpinned by the gender equality principle (Caracciolo Di Torella and Masselot 2013) ${ }^{1}$ the development of EU childcare strategy should be guided by the same principle.

Equally important is the economic imperative. As already mentioned, a coherent strategy on childcare would offer more women the opportunity to work. Indeed, childcare underpins the functioning of the internal market and the lack of such provisions/structure is a major obstacle to the aim of achieving full employment (Connelly 1992, Ribar 1995). Statistics clearly show that a high percentage of individuals, mainly women, cannot participate in full employment because of their primary caregiver responsibilities (Plantenga et al. 2008). Accordingly, the lack of childcare provisions threatens the goal of $75 \%$ employment of the Europe2020 strategy (European Commission 2013, p. 4): in fact childcare responsibilities can have a distinct negative impact on an individual's ability to participate in the employment

\footnotetext{
${ }^{1}$ Other jurisdictions such as New Zealand or Singapore, for instance, have not necessarily taken the concept of gender equality as a central point for developing work-life reconciliation policy (Masselot 2011, 2015).
} 
Final draft (20/06/2015) of an article submitted and accepted for a special issue of the Journal of Social Welfare \& Family Law on 40 Years of Work/Life Balance in the EU: Achievements and Limitations

market (O'Brien 2012). It is therefore baffling that issues relating to childcare have not traditionally been an express part of the EU agenda mostly because of the perceived lack of an economic rationale for such measures. Yet, it is becoming increasingly evident that childcare-related issues are very much integral to the EU's economic development.

The economy benefits from the fact that individuals are actively engaged in paid employment; not having these individuals in the workforce carries indirect costs such as the loss of human resources (European Commission 2011, p. 66). The overall economy further benefits by avoiding the long term consequences of the so-called "old social risks" (Gregory et al. 2013) including unemployment or poverty, as well as the "new social risks" (Bonoli 2005), such as solo parenthood and inadequate social security coverage. If both parents are able to participate in paid work, this would arguably reduce dependence on social welfare benefits. Paid work is also deemed to contribute to women's independence and lead to better outcomes for themselves and their children.

This area shows that the EU's commitment to gender equality is interwoven with economic and market-based considerations, (Bain and Masselot 2013, Garcia and Masselot 2015a, 2015b, Hoskyns 1996, True 2009) yet gender equality (as with other fundamental rights) often conflicts with the free market. In reality, however, the neo-liberal project and economic considerations have often taken precedence over fundamental rights (MacRae 2013) despite legal statements to the contrary (see for example Case 149/77 Defrennes (no. 3) [1978] ECR 1365, paragraphs 26 and 27; Joined Cases 75/82 and 117/82 Razzouk and Beydoun v Commission [1984] ECR 1509; Case C-270/97 Deutsche Post v Sievers \& Schrage [2000] ECR I-929, paragraph 16 and Arnull 1990, Docksey 1991). This constant tension is particularly evident when it comes to childcare policy (Votinious 2013) and goes some way to explain why childcare continues to remain under-regulated.

A second element that may explain the difficulty in addressing childcare, is the lack of express EU competences in this area. Childcare is primarily a component of social welfare (Busby and James in this volume) and as such it remains in the Member States' competence. A discourse on public funding has only recently emerged in domestic policies. Historically, it has developed in the context of specific social and economic challenges that have been addressed differently by individual Western Welfare States. These challenges include the ageing population, the decrease in fertility rates, the fight against child-poverty, the 
Final draft (20/06/2015) of an article submitted and accepted for a special issue of the Journal of Social Welfare \& Family Law on 40 Years of Work/Life Balance in the EU: Achievements and Limitations

management of an increasing diverse workforce in a 24/7 global economy. As a result there are mixed approaches to addressing childcare.

Childcare facilities and arrangements are in fact conceptually and structurally different across the EU Member States. Broadly speaking, they are organised according to a mixture of formal provisions regulated by law or other contractual arrangements, as well as informal, unregulated and often unpaid activities. National childcare policy is shaped and influenced by specific priorities as well as national, cultural, institutional conditions and resources such as they are available (AFEM 2005, Bettio and Plantenga 2004; Caracciolo di Torella and Masselot 2010). Generally speaking, it is possible to affirm that the southern States rely on informal childcare, whilst the role of the State is more prominent in the Nordic and Scandinavian Member States (Saraceno and Keck 2010). Until the 1980's most European countries (with the exception of Sweden (Bjoernberg 2002) adopted policy measures designed to keep women in the private sphere.

In turn, the differences at the domestic level make it difficult to agree on a common EU framework. Indeed, childcare did not feature on the EU agenda until the 1990s and even then, it was not constructed as a precise legal right/obligation or as a fully-fledged strategy, but rather as a policy aim. In other words, the EU childcare strategy is relatively new and tentative (Radulova 2009). In practical terms, this means that under EU law there is no specific right to childcare or right not to be discriminated against because of childcare obligations. Furthermore, the lack of a uniform set of provisions at EU level on childcare reflects and is a consequence of the lack of uniformity at the national level (Social Protection Committee 2014; Horton in this volume).

Finally, strongly engrained gender stereotypes (Masselot et al. 2012) hinder the harmonious development of an EU childcare strategy. Childcare is conceptually framed within the two spheres structure (Crompton and Lyonette 2005, O'Donovan 1984, Rose 1987) where the public one "denote[s] State activity, the values of the marketplace, work, the male domain or that sphere of activity which is regulated by law. By contrast, [the] 'private' [sphere] denotes civil society, the values of family, intimacy, the personal life, home, women's domain or behaviour unregulated by law" (O’Donovan 1984, p. 3). Issues relating to childcare belong to the private sphere and thus are often unpaid, undervalued and not perceived as a "genuine 
Final draft (20/06/2015) of an article submitted and accepted for a special issue of the Journal of Social Welfare \& Family Law on 40 Years of Work/Life Balance in the EU: Achievements and Limitations

economic activity" (see for example Case 53/82 Levin [1982] ECR 1035, Case C-456/02 Trojani v. CPAS [2004] ECR I-7573, para. 24 and Case C-85/96 Martínez Sala v. Freistaat Bayern [1998] ECR I-2691). Women are often considered to be predisposed to provide childcare as an extension of their childbearing ability and also due to women's perceived emotional sensitivity. In this context, it has been easy to argue that women naturally choose this "labour of love" whether informally within the house and or in the (poorly) paid childcare sector. Accordingly, any penalties associated with the provision of childcare is often perceived to result from the (illusion) of life choice exercise (Hakim 2002).

\section{The nature and development of the EU childcare strategy before the $\mathbf{2 0 0 8}$ crisis}

As discussed above, Member States remain in charge of developing their own childcare policies and their engagement in this area fluctuates according to their economic performance (European Commission 2013a; Social Protection Committee 2014; see also Horton in this volume). Thus, at the EU level, childcare strategy has developed under weak leadership and the reluctant participation of Member States. The policy development at the EU level is taking place under the umbrella of the Open Methods of Cooperation in the context of the European Employment Strategy (EES). Since its inception, the role of the EU has been to support, and facilitate information sharing; accordingly in this area few legal instruments none of which are legally binding have been adopted. Furthermore, EU childcare strategy prior to 2008 is framed within the traditional gender equality/market imperative dichotomy, although the main emphasis is supposed to be on gender equality. This is clearly illustrated by the two main EU policy initiatives: the 1992 Childcare Recommendation (Council Recommendation 92/241/EEC O.J. [1992] L123/16) and (ten years later) the European Council 2002 Barcelona objectives (Presidency Conclusions SN 100/1/02 REV).

The Recommendation encourages Member States to take the initiative in creating childcare services; these should be affordable, available and of reasonable quality. It also promotes the adoption of flexibility in the form of special leave, the adaptation of the working environment and structures to reflect the needs of workers with children and encourages a more equal sharing of parental responsibilities. Thus, the Childcare Recommendation is clearly conceptualised within the policy framework of gender equality: this is reflected by the numerous references to shared unpaid domestic tasks. Over the years, this conceptual 
Final draft (20/06/2015) of an article submitted and accepted for a special issue of the Journal of Social Welfare \& Family Law on 40 Years of Work/Life Balance in the EU: Achievements and Limitations

underpinning has gradually been replaced by systematic incorporation into the broader policy framework of employment and economic competitiveness. This trend started with the adoption of the 2002 Barcelona objectives (Presidency Conclusions SN 100/1/02 REV). The European Council adopted a series of objectives aimed at removing the obstacles to women participating in the labour market. In particular, Member States have been encouraged, along with their competent authorities at national, regional and local levels and their social partners, to ensure access to quality childcare facilities, which are affordable to everyone, and are provided for $90 \%$ of children over three years old until they reach school age and, for $33 \%$ of children under the age of three by the year 2010. Reviews of the Barcelona targets in 2008 (COM(2008) 638) and in 2013 (European Commission 2013a, Council conclusion 2011/C/ 155/02) show that such targets are far from being achieved, in particular for children under the age of three, moreover in some countries "the situation appears to deteriorate" (European Commission 2013a, p. 4). In 2010, only ten Member States (namely, Denmark, Sweden, The Netherlands, France, Spain, Portugal, Slovenia, Belgium, Luxembourg and the United Kingdom) had achieved the Barcelona targets for children under three while fifteen States were below 25\% and only eleven States had achieved the objectives of $90 \%$ for children between three years and school age. The Barcelona objectives are strongly positioned under the European strategies for growth and jobs but are also to a lesser degree linked to social inclusion as well as gender equality and work-family reconciliation (Radulova 2009). Despite being directly connected to EU economic growth, the role of the European Commission is limited to promoting the exchange of experiences, ensuring that jobs in this field are more highly valued, and making new recommendations to Member States.

In addition to these policy developments, the Court of Justice of the European Union (CJEU) has also contributed to shaping EU childcare strategy. However, it has not based its judgments on a clear theoretical framework: instead it has used the non-discrimination (rather than equality) principle and an employment based idea of reconciliation between work and family life. These tools are arguably ill-adapted to address this complex issue. As a result, the CJEU's decisions in this area are not always consistent or comprehensive. For example, in Griesmar (Case C-366/99 [2001] ECR I-9383 at para. 55-56), the Court considered that childcare is an obligation faced by parents on an equal basis (as opposed to mothers only). However, a year later in Lommers, (Case C-476/99 [2002] ECR I-2891) it reverted to a 
Final draft (20/06/2015) of an article submitted and accepted for a special issue of the Journal of Social Welfare \& Family Law on 40 Years of Work/Life Balance in the EU: Achievements and Limitations

traditional vision of family organisation when it validated a domestic measure that prioritised access to nursery placement for mothers.

Nevertheless, the CJEU has been instrumental in promoting the value of the role of caregiver and, when possible, linking it into the market scope of the Treaty. In Martínez Sala (Case C85/96 [1998] ECR I-2691), the CJEU considered for the first time whether childcare could be regarded as work for the purpose of free movement of persons (although eventually denying it). Furthermore, in Coleman (Case C-303/06 [2008] ECR-I 415) it created the so-called "discrimination by association" rule, which essentially extends the right to not be discriminated against to protect workers who are treated unfavourably because of the people they care for (Bullock and Masselot 2013; Connor 2010; Horton in this volume).

CJEU's decisions and policy initiatives are interwoven; however, they do not send a cohesive signal because there is no comprehensive strategic aim underpinning EU actions in the area. Nevertheless, it is arguable that case law and policy measures have contributed to shaping a nascent strategy on childcare and, at the least, they have highlighted the need for EU leadership in this field. However, the fact that many EU childcare positions result from $\mathrm{ad}$ hoc responses rather than a coherent strategy has also highlighted some serious shortcomings. In particular, as the Court relies on provisions prohibiting discrimination on the ground of sex, the concept of childcare remains framed as a "woman's responsibility and problem" (see Lommers, Betriu Montull, Foubert in this volume). As the policy serves increasingly as a tool for increasing employment, rather than narrowing the gender gap, women (and parents) face less choice in family organisation and women continue to be subjected to the dual burden of paid work and childcare.

In the decades leading to the 2008 recession, the EU had acknowledged the importance of childcare to the employment rate, gender equality and the economy and it responded by creating a tentative, ill-conceived and sporadic strategy. This was complemented by the Court's decisions responding to ad hoc questions. Thus, overall, EU childcare strategy was weak and uncoordinated but there was nonetheless a clear awareness of its importance and this was underpinned by the principle of gender equality.

III EU childcare strategy post-crisis: the Social Investment Package 2013 
Final draft (20/06/2015) of an article submitted and accepted for a special issue of the Journal of Social Welfare \& Family Law on 40 Years of Work/Life Balance in the EU: Achievements and Limitations

The 2008 recession did not provide the optimal political and economic context from which to build and develop nascent childcare strategy into a fully-fledged childcare policy/law at the EU level. In the immediate aftermath of the 2008 crisis, the EU, occupied with reforming banking and financial markets, adopted no policy on childcare (or indeed on work-life reconciliation). Some have argued that following the 2008 recession, childcare policy and work-family reconciliation in general have slipped off the EU agenda and have been supplanted by neo-liberal arguments. Gregory et al., (2013) claim that the 2008 recession has affected the EU law and policy trajectory on work-family reconciliation in two main ways: First, gender equality is no longer at the heart of policy development on work-family reconciliation; second the pace of legal development has come to a quasi-halt. These can be illustrated by two recent retrenchments. First, despite a campaign led by the European Confederation of Family Organisation (COFACE) to designate 2014 as the European Year for Reconciling Professional and Private Life, the European Commission has refused to make such a designation. Second, the proposed amendments to the Pregnant Workers Directive (Proposal for a Directive amending Council Directive 92/85/EEC COM(2008) 637) introduced within the 2008 work-life package was rejected by the Council in December 2010 and axed by the Commission on 19 June 2014, arguably because it was considered "red tape" (see Foubert in this volume). The underlying assumption in the post-crisis context is that the fundamental principle of gender equality is considered too costly and must take second place to the economic aims of the Treaty.

The crisis undoubtedly had a gender impact entrenched gender stereotypes. In its Strategy for Equality between women and men (European Commission 2010), the European Commission suggested that the recession hindered the achievement of gender equality and that the effect of the crisis would be to put increased pressure on women. In reality, the consequences of the recession have been mixed for both men and women, if negative overall unemployment levels for both men and women are equalizing, although women generally remain in segregated, under-paid and precarious jobs. ${ }^{2}$ In some countries, unemployment levels are accelerating, especially for women as the public sector is shrinking. Public sector cuts disproportionately affect women both as employees and as service users. Thus, the recession

\footnotetext{
${ }^{2}$ Women are not significantly more likely to face unemployment (9.8\%) compared to $9.7 \%$ for men) but they face a higher risk of poverty and exclusion (25.2) than men (23\%) (European Commission 2013b, p. 5, Solera and Bettio 2013).
} 
Final draft (20/06/2015) of an article submitted and accepted for a special issue of the Journal of Social Welfare \& Family Law on 40 Years of Work/Life Balance in the EU: Achievements and Limitations

"appears to have exacerbated the earlier gendered and sectoral pattern of work-life conflict" (Gregory et al. 2013, p. 7). Nevertheless, women's labour market participation appears to have become a lasting feature of contemporary capitalism. Despite the difficulties, the crisis has revealed some durable transformed structures. A majority of women are in paid employment and the crisis has not led them to returning (voluntarily) to the traditional gendered unpaid roles.

The crisis has further highlighted deeply ingrained gender stereotypes in Europe (as illustrated by Masselot et al. 2012). Women are still perceived as the main caregivers, and therefore, not primarily as workers in their own right. The male breadwinner model has not disappeared in most Member States ${ }^{3}$ and the preference for the father as the main economic provider remains a strong cultural force. The persisting gender pay gap of $16.4 \%$ (in the average hourly gross wage) (Eurostat 2014) due in part to women earning lower pay for work of equal value, and in part to job segregation, continues to shape the perception of entitlement and preference in the workplace. This means that work-family reconciliation is viewed as a luxury for women, certainly not a necessity in time of crisis.

Perhaps because of the gender impact of the crisis, the EU's response has ultimately contributed to reinforcing, not weakening, childcare strategy building. Also childcare strategy has the potential to complement and support the policy response to the recession (Crimman et al. 2010) in the form of measures designed to limit or avoid job losses and to support undertakings in retaining their workforce. Childcare measures contribute to the creation of new jobs, however most care-related jobs are undervalued, heavily segregated and often precarious.

If childcare policy development stopped in the immediate aftermath of the 2008 crisis, the production of measures has, from 2010, increased dramatically and has now surpassed any EU activities prior to 2008. The European Parliament has been active through the European Platform for Investing in Children (EPIC) releasing evidence- based reports on childcare amongst other topics. ${ }^{4}$ The European Commission has addressed childcare in at least three communications $(\operatorname{COM}(2010) 491 ; \operatorname{COM}(2010) 2020 ; \operatorname{COM}(2011) 66)$ and in a report on the

\footnotetext{
3 "Women's activity rate is still 12.7 percentage points below that of men (64.9 \% against $77.6 \%$ for the $15-64$ age bracket in 2011), reflecting persistent gender divisions in household and care responsibilities" (European Commission 2013b, p. 5).

${ }^{4}$ http://europa.eu/epic/studies-reports/childcare/index en.htm.
} 
Final draft (20/06/2015) of an article submitted and accepted for a special issue of the Journal of Social Welfare \& Family Law on 40 Years of Work/Life Balance in the EU: Achievements and Limitations

Barcelona targets (European Commission 2010 COM(2008) 638). The Council (2011) in its European Pact for Gender Equality (2011-2020) also restated its commitment to the Barcelona childcare targets.

Most significant so far is the adoption of the 2013 Social Investment Package (SIP), which places childcare at the heart of economic recovery. The SIP is made up of a Commission Communication on Growth and Cohesion (Communication from the Commission $\operatorname{COM}(2013)$ 83) together with a Commission Recommendation on 'Investing in Children: breaking the cycle of disadvantage' (Commission Recommendation 2013/112/EU O.J. [2013] L59) and a series of Staff Working Documents. Under the SIP, the achievement of the Barcelona objectives is said to be central to European priorities both within the Lisbon Strategy and in the Europe 2020 Strategy (European Commission 2013a, p. 4). The failure of Member States to comply with the Barcelona objectives by 2010 and the further deterioration in some Member States since 2011, (European Commission 2013a, p. 4) prompted the Commission to underscore the necessity for the EU to take strong leadership with regards to childcare facilities, which directly contribute to the (economic) objectives of the EU (European Commission 2013a, p. 4).

Against this background, the Commission reaffirms its commitment to childcare policy development and the promotion of gender equality in line with the attainment of the Europe 2020 Strategy. Indeed, the Recommendation calls on EU countries to improve access to affordable early childhood education and care services. It further encourages Member States to step up access to quality childcare services and to support children's participation in extracurricular activities. The Recommendation further proposes a long-term social strategy to support children and to help mitigate the effects of the economic crisis. It provides guidance for Member States on how to tackle child poverty and social exclusion through measures such as family support and benefits, quality childcare and early-childhood education.

The SIP is inextricably linked to the achievement of economic growth and highlights the importance of an economic perspective. In particular, the 2013 Recommendation aims to support parents' access to the labour market and to make sure that work 'pays' for them. It also recommends the provision of adequate income support in the form of measures such as child and family benefits, which should be redistributive across income groups. It urges the need to avoid inactivity traps and stigmatisation. Under the Recommendation, childcare 
Final draft (20/06/2015) of an article submitted and accepted for a special issue of the Journal of Social Welfare \& Family Law on 40 Years of Work/Life Balance in the EU: Achievements and Limitations

becomes an "investment" in individual capacities during the early years. This economic perspective is important because it provides momentum for policy development around childcare.

The SIP moreover introduces the child perspective, which is a new and welcome development. The Recommendation states that it aims to improve the "well-being" and the protection of the rights of children (preamble s 1). This perspective has been called for by scholars (Ackers and Stalford, 2004, Stalford and Drywood 2009) who have persuasively argued that the reconciliation discourse has too often neglected to address children's needs.

Although the SIP provides that the EU's commitments to combating social exclusion and discrimination are fundamental objectives of the EU Treaty and the Charter of Fundamental Rights, $(\operatorname{COM}(2013) 83: 1)$ there are few mentions of gender equality in either the Communication or the Recommendation. The SIP identifies "social exclusion" (not inequality) as a cost to the economy and as a threat to achieving the economic targets set by the Europe 2020 strategy (Communication from the Commission $\operatorname{COM}(2010) 2020$, European Council Conclusions of 17 June 2010). The EU does restate its commitment to the promotion of gender equality in the labour market and in family responsibilities (Recommendation 2013/112/EU: article 2.1), but gender equality principles appear to be only instrumental to the realisation of both economic perspective and children's rights. As the EU childcare strategy appears to have shed most of the gender equality principles, there is a risk that women's roles will become further entrenched in the traditional gendered vision of production and reproduction where the former is valued and the latter is not. If the right of the child takes precedence over gender equality, arguably, it will confirm the so-called 'dominant ideology of motherhood' (McGlynn 2000) where childcare remains gendered, under or unvalued, unaccounted for and often unpaid. The risk is that this will entrench women in traditional domestic roles, or worse, justify their "double shift" (Hochschild and Machung 1989).

\section{Conclusions}

This article has discussed the emergent EU childcare strategy and, in particular, the impact of the 2008 recession. Although initially the EU's childcare strategy developed slowly and unevenly, it was nevertheless strongly underpinned by gender equality concerns. Perhaps 
Final draft (20/06/2015) of an article submitted and accepted for a special issue of the Journal of Social Welfare \& Family Law on 40 Years of Work/Life Balance in the EU: Achievements and Limitations

paradoxically, following the 2008 financial crisis, EU childcare strategy while remaining soft in nature, seems to have picked up speed and a more coherent structure has appeared. There continues to be tension between economic aims and social norms but a preference for the economic aims seems to be emerging. The initial EU leadership with the adoption of the SIP continues to be undermined by the Member States' reticence in this area.

The adoption of the Social Investment Package in 2013 marks significant change in the approach taken by the EU in relation to childcare. First the EU makes childcare a relevant concept for the EU market and secondly the post-crisis concept of childcare primarily serves economic growth and the right of the child. Gender equality thus becomes a secondary aim of childcare policy. Moreover, the EU growth Strategy (Europe 2020) which talks about a "changing world" entrenches the traditional gendered vision of production and reproduction where the former is valued and the latter is not. As a result, childcare remains gendered, under-valued, unaccounted for and often unpaid.

Is there retrenchment of the core values in the EU childcare strategy? Certainly, gender equality is vanishing from the main aims of childcare strategy. However, the introduction of core values such as social exclusion and social justice are to be welcomed. It is possible that the economic crisis has served to highlight existing structural inequalities. However, the values embedded in the Treaty (solidarity, human dignity and gender equality) can provide strong guidelines for the development of good quality, affordable and accessible childcare facilities. This encompasses care facilities for all dependants: adults and children alike. If developed under appropriate guiding principles, including gender equality, the articulation of childcare policy has the potential to provide a blue print for the development of all forms of care across the EU.

Under the SIP childcare is considered to be an "investment" in the future. This market term, obscures the fact that the need for care is vastly broader than just "child"-care. The looming problematic of demographic is very pertinent: increased life expectancy coupled with an ageing society means that a far larger proportion of the population is likely to become in need of care in the coming decades. The EU remains silent with regard to other forms of care. However, a coherent childcare strategy may serve as a springboard for developing strategies for other forms of care. 
Final draft (20/06/2015) of an article submitted and accepted for a special issue of the Journal of Social Welfare \& Family Law on 40 Years of Work/Life Balance in the EU: Achievements and Limitations

\section{References}

\section{Legislation}

Communication from the Commission, 'A Better Work-Life Balance: Stronger Support for Reconciling Professional, Private and Family Life', COM(2008) 635

Communication from the Commission of 21 September 2010, 'Strategy for equality between women and men 2010-2015', COM (2010) 491

Communication from the Commission of 3 March 2010, 'Europe 2020 Strategy, A strategy for smart, sustainable and inclusive growth', $\operatorname{COM}(2010) 2020$.

European Commission 2010a, Communication on Strategy for Equality between Women and Men, 2010-2015, COM(2010)491 final, European Commission, Brussels.

Communication from the Commission of 17 February 2011, 'Early Childhood Education and Care: Providing all our children with the best start for the world of tomorrow, $\operatorname{COM}(2011) 66$

Communication from the Commission to the European Parliament, the Council, the European Economic and Social Committee and the Committee of the Regions, Towards Social Investment for Growth and Cohesion - including implementing the European Social Fund 2014-2020, 20 February 2013, COM(2013) 83.

Council conclusions of 7 March 2011 on European Pact for Gender Equality (2011-2020) $(2011 / \mathrm{C} 155 / 02)$

Council Directive 92/85/EEC of 19 October 1992 on the introduction of measures to encourage improvements in the safety and health at work of pregnant workers and workers who have recently given birth or are breastfeeding (tenth individual Directive within the meaning of Article 16 (1) of Directive 89/391/EEC), O.J. [1992] L348/1.

Council Directive 97/81/EC of 15 December 1997 concerning the Framework Agreement on part-time work concluded by UNICE, CEEP and the ETUC - Annex: Framework agreement on part-time work O.J. [1998] L014/9. 
Final draft (20/06/2015) of an article submitted and accepted for a special issue of the Journal of Social Welfare \& Family Law on 40 Years of Work/Life Balance in the EU: Achievements and Limitations

Council Directive 1999/70/EC of 28 June 1999 concerning the framework agreement on fixed-term work concluded by ETUC, UNICE and CEEP O.J. [1999] L175/43.

Council Directive 2010/18/EU of 8 March 2010 implementing the revised Framework Agreement on parental leave concluded by BUSINESSEUROPE, UEAPME, CEEP and ETUC and repealing Directive 96/34/EC (Text with EEA relevance) O.J. [2010] L68/13.

Council Recommendation 92/241/EEC of 31 March 1992 on child care O.J. [1992] L123/16.

Directive 2003/88/EC of the European Parliament and of the Council of 4 November 2003 concerning certain aspects of the organisation of working time O.J. [2013] L299/9.

European Commission Recommendation of 20 February 2013, Investing in children: breaking the cycle of disadvantage (2013/112/EU) O.J. 2013 L59.

European Commission Report of 3 October 2010, 'Implementation of the Barcelona objectives concerning childcare facilities for pre-school-age children' $\{\operatorname{SEC}(2008) 2597\} \operatorname{COM}(2008) 638$.

European Council Conclusions of 17 June 2010 "A new European Strategy for jobs and growth" EUCO 13/10.

Presidency Conclusions, Barcelona European Council 15 and 16 March 2002, SN 100/1/02 REV

http://ec.europa.eu/invest-inresearch/pdf/download_en/barcelona_european_council.pdf.

Proposal for a Directive on the application of the principle of equal treatment between men and women engaged in an activity in a self-employed capacity and repealing Directive 86/613/EEC, COM(2008) 636.

Proposal for a Directive amending Council Directive 92/85/EEC on the introduction of measures to encourage improvements in the safety and health at work of pregnant workers and workers who have recently given birth or are breastfeeding, $\operatorname{COM}(2008)$ 637.

\section{Articles}


Final draft (20/06/2015) of an article submitted and accepted for a special issue of the Journal of Social Welfare \& Family Law on 40 Years of Work/Life Balance in the EU: Achievements and Limitations

Association des Femmes de l'Europe Méridionale (AFEM), 2005. Concilier Vie Familiale et Vie Professionnelle Pour les Femmes et les Hommes : Du Droit A la Pratique. Athens: Sakkoulas and Brussels : Bruylant.

Ackers, L. and Stalford, H., 2004. A community for children?: Children, Citizenship and Internal Migration in the EU. Aldershot: Ashgate.

Arnull, A., 1990. General principles of EC law and the individual. Leicester: Leicester University Press.

Bain, J. and Masselot, A., 2013. Gender Equality Law and Identity Building for Europe. Canterbury law review, 18, 99-120.

Bell, M., 2011. The principle of equal treatment: Widening and deepening. In P. Craig and G. De Búrca, eds. The Evolution of EU Law. Oxford: Oxford University Press, 611-639.

Bettio, F. and Plantenga J., 2004. Comparing Care Regimes in Europe. Feminist economics, $10,85-113$.

Bjoernberg, U., 2002. Ideology and choice between work and care: Swedish family policy for working parents. Critical social policy, 22, 33-52.

Bonoli, G., 2005. The Politics of the New Social Policies: Providing Coverage against New Social Risks in Mature Welfare States. Policy and politics, 33 (3), 431-449.

Bullock, J. and Masselot, A., 2013. Multiple Discrimination and Intersectional Disadvantages: Challenges and Opportunities in the European Union Legal Framework. Columbia journal of european law, 19, 55-80.

Caracciolo di Torella, E. and Masselot, A., 2010. Reconciling Work and Family Life in EU Law and Policy. London: Palgrave Macmillan.

Caracciolo Di Torella, E. and Masselot, A., 2013. Work and Family Life Balance in the EU law and policy 40 years on: still balancing, still struggling. European gender equality law review, 2, 6-14.

Caracciolo di Torella, E., 2014. Brave New Fathers for a Brave New World? Fathers as Caregivers in an Evolving European Union. European law journal, 20 (1), 88-106.

Connelly, R., 1991. The Importance of Child Care Costs on Women's Decision-Making. In D. Blau ed. The economics of child care. New York: Russell Sage Foundation, 87-117. 
Final draft (20/06/2015) of an article submitted and accepted for a special issue of the Journal of Social Welfare \& Family Law on 40 Years of Work/Life Balance in the EU: Achievements and Limitations

Connor, T., 2010. Discrimination by association: a step in the right direction Case C-303/06 Coleman v. Attridge Law and Steve Law. Judgment of the ECJ 17 July 2008. Journal of social welfare \& family law, 32 (1), 59-69.

Crimman, A. Wiener, F. and Bellman, L., 2010. The German work-sharing scheme: an instrument for the crisis. International labour organization. Conditions of Work and Employment Series No. 25.

Crompton, R. and Lyonette, C., 2005. The new gender essentialism - domestic and family "choices" and their relation to attitudes. British Journal of Sociology, 56 (4), 601-620.

Docksey, C., 1991. The Principle of the equality between women and men as a fundamental right under community law. Industrial law journal, 20 (4), 258-280.

European Commission report, 2008. Implementation of the Barcelona Objectives Concerning Facilities for Pre-School-Age Children. COM(2008) 638.

European Commission, 2013a. Report from the Commission to the European Parliament, the Council, the European Economic and Social Committee of the Region, Barcelona Objectives, The development of childcare facilities for young children in Europe with a view to sustainable and inclusive growth. Luxembourg: Publications office of the European Union.

European Commission 2013b, Social investment package: Key facts and figures.

Eurostat, 2014. Gender pay Gap statistics. < http://ec.europa.eu/eurostat/statisticsexplained/index.php/Gender_pay_gap_statistics\#cite_note-1 >

Garcia, M. and Masselot, A., 2015a. The Value of Gender Equality in the EU-Asian Trade Policy: an assessment of the EU's ability to implement its own legal obligations. In A. Björkdahl, N. Chaban, J. Leslie and A. Masselot eds. Importing EU Norms? Conceptual Framework and Empirical Findings. Dordrecht: Springer, 191-209.

Garcia, M. and Masselot, A., 2015b. EU-Asia Free Trade Agreements as tools for social norm/legislation transfer. Asia-Europe Journal DOI: 10.1007/s10308-015-0423-0

Gregory, A., Milner, S. and Winderbank, J., 2013. Work-Life balance in time of economic Crisis and austerity. International journal of sociology and social policy,33 (9/10), 528541. 
Final draft (20/06/2015) of an article submitted and accepted for a special issue of the Journal of Social Welfare \& Family Law on 40 Years of Work/Life Balance in the EU: Achievements and Limitations

Hakim, C., 2002. Lifestyle Preferences as Determinants of Women's Differentiated Labor Market Careers. Work and occupations, 29 (4), 428-459.

Hervey, T., 2001. Up in Smoke: Community (anti) tobacco law and policy. European law review, 26, 101-125.

Hochschild, A. and Machung, A., 1989. The second shift: working parents and the revolution at home. New York: Viking Penguin.

Hoskyns, C., 1996. Integrating gender: Women, law and politics in the European Union. London: Verso.

Koukoulis-Spiliotopoulos, S., 2008. The Lisbon Treaty and the Charter of Fundamental Rights: Maintaining and developing the aquis in gender equality. European gender equality law review, 1, 15-24.

Lewis, J., 2006. Work/Family Reconciliation, Equal Opportunities and Social Policies: the Interpretation of Policy Trajectories at the EU Level and the Meaning of Gender Equality. Journal of Public Policy, 13 (3), 420-437.

Lewis, J., Knijn, T., Martin, C. and Ostner, I., 2008. Patterns of developments in work/family reconciliation policies for parents in France, Germany, The Netherlands and the UK in the 2000s. Social politics, 15 (13), 261-286.

MacRae, H., 2013. (Re-)Gendering integration: Unintended and unanticipated gender outcomes of the European Union policy. Women's studies international forum, 39, 3-11.

Masselot A., 2011. The Right and Reality of Flexible Working Arrangements in New Zealand. In G. James and N. Busby eds. Families, Care-Giving and Paid Work, Cheltenham: Edward Elgar, 69-85.

Masselot, A., Caracciolo di Torella, E., and Burri, S., 2012. Thematic Report of the European Network of Legal Experts in the Field of Gender Equality "Fighting Discrimination on the Grounds of Pregnancy, Maternity and Parenthood - The application of EU and national law in practice in 33 European countries", Brussels: Publication of the European Commission. 
Final draft (20/06/2015) of an article submitted and accepted for a special issue of the Journal of Social Welfare \& Family Law on 40 Years of Work/Life Balance in the EU: Achievements and Limitations

Masselot, A., 2015. Gender Implications of the Right to Request Flexible Working Arrangements: Raising Pigs and Children in New Zealand. New Zealand Journal of Employment Relations, 39 (3), 59-71.

McGlynn, C., 2000. Ideologies of Motherhood in European Community Sex Equality Law. European law journal, 6, 29-44.

Numhauser-Henning, A., and Rönmar M. eds., 2013. Normative Patterns and Legal Developments in the Social Dimension of the EU. Hart: Oxford

O'Brien, C., 2012. Confronting the care penalty: the case for extending reasonable adjustment rights along the disability/care continuum. Journal of Social Welfare \& Family Law, 34 (1), 5-30.

O’Donovan, K., 1984. Sexual Divisions in Law. London: Weidenfeld \& Nicolson.

Plantenga, J., Remery, C., Siegel, M., and Sementini, L., 2008. Childcare services in 25 European Union member states: The Barcelona targets revisited. In A. Leira, and C. Saraceno eds. Childhood: Changing Contexts (Comparative Social Research, Volume 25 Bingley: Emerald Group, 27-53.

Radulova, E., 2009. The construction of EU's childcare policy through the Open Method of Coordination. In Kröger, S. ed. What we have learnt: Advances, pitfalls and remaining questions in OMC research, European Integration online Papers (EIoP), Special Issue 1, Vol. 13, Art. 13. http://eiop.or.at/eiop/texte/2009-013a.htm.

Ribar, D., 1995. A Structural Model of Child Care and the Labor Supply of Married Women. Journal of labor economics, 13 (3), 558-597.

Rose, N., 1987. Beyond the Public/Private Division: Law Power and the Family. Journal of law and society, 14, 61-76.

Saraceno, C., and Keck, W., 2010. Can we identify intergenerational policy regimes in Europe? European societies, 12 (5), 675-696.

Sapir, A., 2006, Globalization and the Reform of the European Social Model. Journal of common market studies, 44 (2), 369-390. 
Final draft (20/06/2015) of an article submitted and accepted for a special issue of the Journal of Social Welfare \& Family Law on 40 Years of Work/Life Balance in the EU: Achievements and Limitations

Smith, M. and Villa, P., 2013. Making gender equality part of the solution. In F. Bettio, J. Platenga and S. Smith eds. Gender and the European Labour Market. Routledge: London, 224-241.

Social Protection Committee, 2014. Social Europe - Aiming for inclusive growth - Annual report of the Social Protection Committee on the social situation in the European Union $(10 / 03 / 2015)$.

Solera, C. and Bettio, F., 2013. Women's Continuous Careers in Italy: The Education and Public Sector Divide. Population review, 52 (1), http://muse.jhu.edu/.

Stalford, H., and Drywood, E., 2009. Coming of age? : Children's rights in the European Union. Common market law review, 46 (1), 143-172.

True, J., 2009. Trading-off gender equality for global Europe? The European Union and free trade agreements. European Foreign Affairs Review, 14, 723-742.

Votinious, J., 2013. Parenthood meets Market-Functionalism: Parental rights in the Labour Market and the Importance of the Gender Dimension. In A. Numhauser-Henning and M. Rönmar eds. Normative Patterns and Legal Developments in the Social Dimension of the $E U$. Oxford: Hart. 